ISSN 1029-8940 (Print)

ISSN 2524-230X (Online)

UDC 574.583(285.2)

https://doi.org/10.29235/1029-8940-2020-65-3-310-318

Received 21.02.2020

\author{
Zhanna F. Buseva ${ }^{1}$, Shabnam G. Farahani ${ }^{1}$, Elena A. Sysova ${ }^{1}$, Davis Ozolins ${ }^{2}$, \\ Nadezhda N. Sushchik ${ }^{3}$, Angelika A. Kolmakova ${ }^{3}$, Yulia K. Veras ${ }^{4}$ \\ ${ }^{I}$ Scientific and Practical Center for Bioresources of the National Academy of Sciences of Belarus, \\ Minsk, Republic of Belarus \\ ${ }^{2}$ Institute of Biology of the University of Latvia, Salaspils, Latvia \\ ${ }^{3}$ Institute of Biophysics of the Siberian Branch of the Russian Academy of Sciences, \\ Krasnoyarsk, Russian Federation \\ ${ }^{4}$ Belarusian State University, Naroch, Minsk Region, Republic of Belarus
}

\title{
SEASONAL CHANGES IN THE PHYTOPLANKTON TAXONOMIC STRUCTURE AND PHOTOSYNTHETIC PIGMENTS IN PELAGIAL AND LITTORAL OF TWO INTERCONNECTED LAKES IN BELARUS
}

\begin{abstract}
The seasonal pattern of phytoplankton taxonomical composition and phytoplankton chlorophyll $a$ content from pelagial and littoral locations with and without macrophyte beds in two interconnected lakes (north-west of Belarus) under contrasting trophic conditions were studied. We estimated influence of hydrochemical parameters on phytoplankton in studied lakes. There was "a clear water phase" in pelagial and low phytoplankton abundance in littoral of mesotrophic Lake Obsterno but we revealed a brief pulse of Chrysophyta and "a late spring bloom" with high total phytoplankton abundance in shallow macrophyte-covered low trophic state Lake Nobisto. It was found some prominent differences in total phytoplankton abundance and taxonomic composition in littoral and pelagial locations of both lakes. We used Phyto-Pam phytoplankton analyser for analysis of algae pigments. Phyto-Pam method allowed roughly identify two types of pigments - pigments of green algae and diatoms and revealed differences in concentrations of pigments between littoral locations and pelagial in both lake types. Results indicated that total chlorophyll $a$ content has a pronounced seasonal cycle with high values during the early fall and low values throughout the late spring in mesotrophic lake and have shown differences in phytoplankton pigments between lakes littoral locations.

Keywords: phytoplankton, pigments, chlorophyll $a$, seasonal changes, littoral, pelagial, macrophyte beds, mesotrophic lake, shallow lake

For citation: Buseva Zh. F., Farahani Sh. G., Sysova E. A., Ozolins D., Sushchik N. N., Kolmakova A. A., Veras Yu. K. Seasonal changes in the phytoplankton taxonomic structure and photosynthetic pigments in pelagial and littoral of two interconnected lakes in Belarus. Vestsi Natsyyanal'nai akademii navuk Belarusi. Seryya biyalagichnykh navuk= Proceedings of the National Academy of Sciences of Belarus. Biological series, 2020, vol. 65, no. 3, pp. 310-318. https://doi.org/10.29235/1029-8940-202065-3-310-318
\end{abstract}

Ж. Ф. Бусева ${ }^{1}$, Ш. Г. Фарахани ${ }^{1}$, Е. А. Сысова ${ }^{1}$, Д. Озолиньш ${ }^{2}$, Н. Н. Сущик ${ }^{3}$, А. А. Колмакова ${ }^{3}$ Ю. К. Верес ${ }^{4}$

\footnotetext{
${ }^{\prime}$ Научно-практический центр НАН Беларуси по биоресурсам, Минск, Республика Беларусь

${ }^{2}$ Институт биологии Латвийского университета, Саласпилс, Латвия

${ }^{3}$ Институт биофизики Сибирского отделения Российской академии наук, Красноярск, Россия

${ }^{4}$ Белорусский государственный университет, Нарочь, Республика Беларусь

СЕЗОННЫЕ ИЗМЕНЕНИЯ ТАКСОНОМИЧЕСКОЙ СТРУКТУРЫ

И ФОТОСИНТЕТИЧЕСКИХ ПИГМЕНТОВ ФИТОПЛАНКТОНА В ПЕЛАГИАЛИ И ЛИТОРАЛИ ДВУХ СООБЩАЮЩИХСЯ ОЗЕР В БЕЛАРУСИ
}

Аннотация. Исследованы сезонные изменения таксономической структуры и фотосинтетических пигментов фитопланктона в пелагиали, а также в литорали, заросшей разными видами макрофитов, и литорали без зарослей в двух сообщающихся озерах разного трофического статуса (северо-запад Беларуси). Установлено, что для мезотрофного оз. Обстерно весной характерна «фаза чистой воды» в пелагиали и низкая численность фитопланктона в литорали. В то же время высокая численность хризофитовых водорослей (Chrysophyta) вызывала «осеннее цветение» фитопланктона в мелководном макрофитного типа оз. Нобисто с низкой трофностью. Выявлены существенные различия в общей численности и таксономической структуре фитопланктона между пелагиалью и литоралью в обоих озерах. С помощью специального метода с использованием прибора Phyto-Pam для определения содержания пигментов различных групп водорослей - зеленых и диатомовых и общего хлорофилла $a$ установлено, что общее содержание хлорофилла $а$ имело выраженный сезонный цикл с пиком ранней осенью и низким содержанием весной в ме- 
зотрофном озере, а уровни хлорофилла $а$ в литорали двух исследованных озер существенно различались. Согласно полученным данным, указанный метод может использоваться только для быстрого определения или грубой оценки содержания хлорофилла $a$ в водоемах.

Ключевые слова: фитопланктон, пигменты, хлорофилл $a$, сезонные изменения, литораль, пелагиаль, заросли макрофитов, мезотрофное озеро, мелководное озеро

Для цитирования: Сезонные изменения таксономической структуры и фотосинтетических пигментов фитопланктона в пелагиали и литорали двух сообщающихся озер в Беларуси / Ж. Ф. Бусева [и др.] // Вес. Нац. акад. навук Белаpусі. Сер. біял. навук. - 2020. - Т. 65, № 3. - С. 310-318 (in English). https://doi.org/10.29235/1029-8940-2020-65-3-310-318

Introduction. Clear differences exist in algal species composition, both between lakes and within a single lake over time, but the relative importance of nutrient competition among different taxa and purely physical processes among variable taxa in different seasons have not been clarified yet [1,2] in the literature, a large number of methods are available to measure chlorophyll from phytoplankton [3]. Phytoplankton pigment are measured directly by means of spectrophotometric or fluorometric procedures $[4,5]$. Chlorophyll $a$ values are also used to calculate phytoplankton carbon biomass, assuming a fixed carbon to the chlorophyll $a$ ratio. A number of older reports in the literature, mostly based on studies of the laboratory phytoplankton cultures, have demonstrated upper and lower limits on what one might expect in nutrient/chlorophyll relationships [6]. Since the early work of [7], chlorophyll fluorescence has become increasingly important for assessment of phytoplankton biomass and primary productivity [8]. Very sensitive techniques have been developed to measure chlorophyll $a$ content and to analyse basic parameters of photosynthetic activity in natural surface waters down to $0.1 \mu \mathrm{g} \cdot \mathrm{Chl}^{-1}[9,10]$. The so far available instrumentation has been limited by the fact that it cannot distinguish between different groups of phytoplankton, like green algae, diatoms and blue-green algae. In principle, such distinction is possible on the basis of the specific fluorescence excitation properties of differently pigmented phytoplankton groups [11]. We are aware that the chlorophyll $a$ content generally differs between pelagic and littoral zones in the lakes and that the shallow areas are more influenced by the benthic processes than the pelagic zones $[12,13]$.

The goal of this study was to define seasonal patterns of phytoplankton composition of two interconnected lakes under contrasting - mesotrophic and low trophic conditions and estimated hydrochemical factors regulating phytoplankton structure during vegetation season.

Materials and research methods. Lake Obsterno $\left(55^{\circ} 37^{\prime} 31.9^{\prime \prime} \mathrm{N}, 27^{\circ} 21^{\prime} 55.2^{\prime \prime} \mathrm{E}\right)$ is a mesotrophic relatively shallow lake with surface area of $9.89 \mathrm{~km}^{2}$, max depth $12 \mathrm{~m}$, mean depth of $5.3 \mathrm{~m}$. The lake has a wide macrophyte beds occupying most of the shallow water area in littoral zone. Interconnected low tropic state Lake Nobisto $\left(55^{\circ} 37^{\prime} 55.9^{\prime \prime} \mathrm{N}, 27^{\circ} 24^{\prime} 19.9^{\prime \prime} \mathrm{E}\right)$ with $3.75 \mathrm{~km}^{2}$ surface area is shallow, has a max and mean depths of 2.8 and $1.4 \mathrm{~m}$ respectively. Lake Nobisto has a right-side shoreline with a swamped territory and the wide and dense macrophyte beds grow all around this lake, common bladderwort (Utricularia vulgaris L. of Lentibulariaceae family, order Lamiales) cover all the lake's bottom.

A total of 48 samples from seven habitats of two lakes in different seasons (with three replications for each habitat) were analysed for phytoplankton taxonomy. The phytoplankton samples of mesotrophic Lake Obsterno were collected in late May to September 2016 to identify the taxa in four locations pelagial (depth of 4.5-5 m), bare littoral - an open shallow area without macrophytes, rush beds Schoenoplectus lacustris (L.) and yellow water-lily zone Nuphar lutea (L.). In Lake Nobisto, samples were collected from three habitats - one of pelagial (depth of $2.3 \mathrm{~m}$ ) and two sites in littoral - bare littoral location and bull rush beds Phragmites australis (Cav.) Trinex Steud. (approximate depths of 1.2 and $0.7 \mathrm{~m}$ respectively) in 2017. The samples were kept in 1 liter jars and fixed with $2 \%$ formalin solution. Each season all samples were taken during a day field trip. Data from Lake Obsterno were divided between a warm, more productive period (spring) and the cool and less productive period of the year (autumn). Species identification and counting of algal number were carried out in the Fuchs-Rosenthal chamber using a light microscope with a magnification of $\times 360$.

Phyto-Pam phytoplankton analyser was applied to get a quick measurement of chlorophyll a concentration in phytoplankton samples $\left(\mu \mathrm{g} \cdot \mathrm{l}^{-1}\right)$ without using acetone on the basis of the specific fluorescence excitation properties of differently pigmented phytoplankton groups. For this technique, due to the storage condition, we selected May and September phytoplankton samples of Lake Obsterno in 2016 and only September samples of Lake Nobisto in 2017. We performed sampling two years in different lakes but two seasons did not differ crucially in weather conditions. 
The Phyto-Pam (Phyto-PAM phytoplankton Analyzer, Heinz Walz GMBH, Effeltrich, Germany) employs light-emitting-diodes (LED) to excite chlorophyll $a$ fluorescence alternatingly by $10 \mu$ s light pulses at four different wave lengths $(470,535,620$ and $650 \mathrm{~nm})$. The fluorescence pulses were detected by a photomultiplier and amplified under microprocessor-control, resulting in 4 separate continuous signals (4 channels).

Seston samples for carbon, nitrogen and phosphorus analysis were stored in (one liter) plastic bottles that were first washed and rinsed in distilled and deionized water. Particulate samples were collected onto precombusted $\left(5 \mathrm{~h} \mathrm{in} 400^{\circ} \mathrm{C}\right.$ ) glass fiber filters (Microbio GF/F filters, $0.7 \mu \mathrm{m}$ porosity, $37 \mathrm{~mm}$ diameter) and after filtration dried at $60^{\circ} \mathrm{C}$ for $72 \mathrm{~h}$. Final volume of filtering water on GF/F for seston was $0.8-1.21$. All samples were taken once a day at around 10:00-12:00 o'clock. Flash EA 1112 NC Soil/MAS 200, Thermo Quest, Italy, CHN analyzer was used for carbon (C) and nitrogen (N) measurement. Particulate matter was analyzed for phosphorus $(\mathrm{P})$ content calorimetrically after persulfate oxidation via spectrophotometer [14].

Statistical analyses. All statistical analyses were conducted using Minitab 17. To test the significant differences among habitats with phytoplankton taxonomical composition, we used one-way ANOVA with Tukey post hoc test. Eigen analysis of the correlation matrix via Principal Component Analysis (PCA) was applied to determine correlation between total abundance of phytoplankton dominant groups with elements as well as water chemistry.

Results and its discussion. During this study, water temperature varied from $21.4{ }^{\circ} \mathrm{C}$ in May with maximum of $23.6^{\circ} \mathrm{C}$ in littoral location to September $14.3^{\circ} \mathrm{C}$ in Lake Obsterno. Among all physicochemical and hydrochemical parameters, TDS (115-120 ppm) and $\mathrm{pH}$ didn’t change in a significant way but dissolved nitrates, phosphates and ammonium were not balanced in the whole season (Tab. 1). The Secchi disc transparency in Lake Obsterno differed from spring to autumn shifted from $6.5 \mathrm{~m}$ maximum in May to $4.2 \mathrm{~m}$ minimum in September.

T a b l e 1. Hyrdochemical and physical parameters of Lake Obsterno (2016)

\begin{tabular}{|c|c|c|c|c|}
\hline \multirow{3}{*}{ Parameter } & \multicolumn{4}{|c|}{ Season, location } \\
\hline & Pelagial & Littoral & Pelagial & Littoral \\
\hline & \multicolumn{2}{|c|}{ May } & \multicolumn{2}{|c|}{ September } \\
\hline$T,{ }^{\circ} \mathrm{C}$ & 21.4 & $22.43 \pm 0.5$ & 14.4 & $14.3 \pm 0.1$ \\
\hline $\mathrm{pH}$ & 8.4 & $8.5 \pm 0.05$ & 8.4 & $8.7 \pm 0.00$ \\
\hline Secchi depth, m & \multicolumn{2}{|c|}{6.5} & \multicolumn{2}{|c|}{4.2} \\
\hline $\mathrm{PO}_{4}, \mathrm{mg} \cdot \mathrm{l}^{-1}$ & 0.39 & $0.37 \pm 0.08$ & 3.1 & $1.32 \pm 0.51$ \\
\hline $\mathrm{NO}_{3}, \mathrm{mg} \cdot \mathrm{l}^{-1}$ & 0.3 & $0.6 \pm 0.10$ & 0.3 & $1.1 \pm 0.26$ \\
\hline $\mathrm{NH}_{4}, \mathrm{mg} \cdot \mathrm{l}^{-1}$ & 0.15 & $0.27 \pm 0.01$ & 0.03 & $0.21 \pm 0.08$ \\
\hline
\end{tabular}

N o t e. Data for littoral is represented means from all three locations (means $\pm \mathrm{SD}$ ).

In Lake Nobisto during the autumn, temperature, $\mathrm{pH}$, TDS (100-110 ppm) and nitrate (Tab. 2) did not change in a significant way among habitats while $\mathrm{NH}_{4}^{+}$and $\mathrm{PO}_{4}^{3-}$ were different in comparing with Lake Obsterno. The Secchi disc transparency in Lake Nobisto was high ( $2.9 \mathrm{~m}$ till the bottom).

T a b l e 2. Hydrochemical parameters of Lake Nobisto (autumn 2017)

\begin{tabular}{|l|c|c|c|}
\hline \multirow{2}{*}{\multicolumn{1}{|c|}{ Parameter }} & \multicolumn{3}{|c|}{ Location } \\
\cline { 2 - 4 } & Pelagial & Bare littoral & Bull rush \\
\hline$T,{ }^{\circ} \mathrm{C}$ & 9.6 & 9.6 & 9.8 \\
\hline $\mathrm{pH}$ & 8.6 & 8.5 & 8.6 \\
\hline $\mathrm{Secchi} \mathrm{depth}, \mathrm{m}$ & \multicolumn{3}{|c|}{} \\
\hline $\mathrm{PO}_{4}, \mathrm{mg} \cdot l^{-1}$ & 2 & 2.9 & 1.04 \\
\hline $\mathrm{NO}_{3}, \mathrm{mg} \cdot l^{-1}$ & 0 & 1.84 & 0.2 \\
\hline $\mathrm{NH}_{4}, \mathrm{mg} \cdot l^{-1}$ & 0.77 & 0 & 1.56 \\
\hline
\end{tabular}




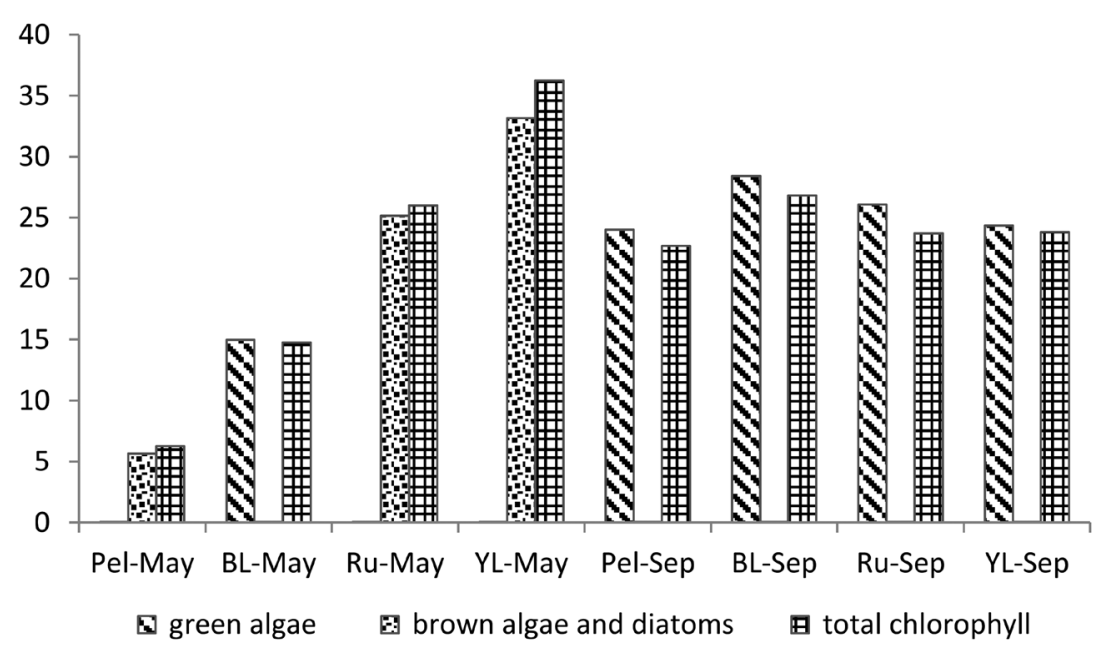

Fig. 1. Chlorophyll $a$ concentration $\left(\mu \mathrm{g} \cdot \mathrm{l}^{-1}\right)$ of phytoplankton samples in different habitats of Lake Obsterno. Sep - September, Pel - Pelagial, BL - Bare littoral, Ru - Rush beds, YL - Yellow lily beds

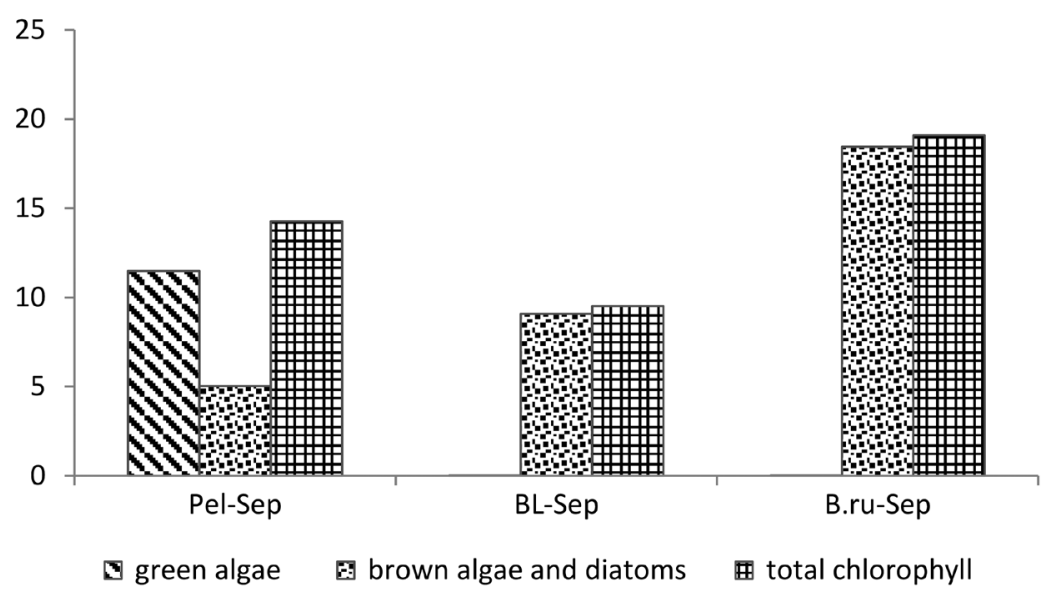

Fig. 2. Chlorophyll $a$ concentration $\left(\mu \mathrm{g} \cdot \mathrm{l}^{-1}\right)$ of phytoplankton samples in different habitats of Lake Nobisto. Sep - September, Pel - Pelagial, B. ru - Bull rush, BL - Bare littoral

During this study, total chlorophyll $a$ concentrations ranged from 6.25 to $36.24 \mu \mathrm{g} \cdot 1^{-1}$ in Obsterno and from 9.51 to $19.10 \mu \mathrm{g} \cdot \mathrm{l}^{-1}$ in Nobisto, averaging $22.84 \pm 8.84$ and $14.29 \pm 4.79 \mu \mathrm{g} \cdot \mathrm{l}^{-1}$ in Obsterno and Nobisto respectively (Fig. 1,2). Peak concentrations occurred during late spring in yellow water-lily zone in Lake Obsterno. In general, chlorophyll $a$ was lower in Nobisto than in Obsterno. The minimum chlorophyll $a$ concentrations were typically observed at the pelagial zone of Lake Obsterno at the end of May where we noted "a clear water phase" as recorded in many studies [15]. Spring phytoplankton usually characterizes the "diatom bloom", so brown pigments appeared in Lake Obsterno. The shallow location without macrophyte cover (bare littoral) is more turbid lake's area where the pigments of green algae were identified properly in our phytoplankton samples of that location which is completely in agreement with Happey and Woods research in 1988 [16].

The chlorophyll $a$ content revealed differences in pigments in accordance with dominant groups such as green algae and diatoms in autumn and late May in Obsterno as well as diatoms in Nobisto during autumn. The Secchi disc transparency in Obsterno from May to September decreased greatly (from 6.5 to $4.2 \mathrm{~m}$ ) in combination the shift in dominant groups from diatoms to green algae. Taxonomical composition of phytoplankton has shown differences in lakes during season as well as in littoral and pelagial locations. In Lake Obsterno in May Chrysophyta and then Bacillariophyta were the most abundant algae groups in pelagial, bare littoral, rush beds and yellow water-lily zone respectively. In autumn, Bacillariophyta was the most widespread group in all habitats (Tab. 3). According to the phytoplankton community composition of Lake Nobisto, during autumn in pelagial Chrysophyta but in bare littoral and bulrush, 
Bacillariophyta were the dominant groups (Tab. 4). Cyanophyta were absent in May in pelagial and bare littoral and had minimum values in rush beds and yellow water lily zone in Lake Obsterno. In lake Nobisto we identified minimum values of Cyanophyta in all habitats in autumn. Meanwhile during May and September within all habitats of both lakes, no chlorophyll content for blue-green algae (Cyanophyta) by using Phyto Pam technique was obtained. As noted by Moore in 1978 [17], numerous factors may be involved in the ecological success of blue-green algae. One proposed explanation for low dominance of blue-green algae is limited phosphorus since nitrogen-fixing species usually are those who dominate [18] which is in agreement with our data and low trophic state of both lakes.

$\mathrm{T}$ a b 1 e 3. Taxonomical composition of phytoplankton community of Lake Obsterno: abundance (ind/l) and C:N, N:P ratios of seston within season (from May to September) 2016

\begin{tabular}{|c|c|c|c|c|}
\hline Habitat & Phytoplankton group & Mean \pm SD & $\mathrm{C}: \mathrm{N}$ & $N: P$ \\
\hline \multirow[t]{5}{*}{ Pelagial } & Bacillariophyta & $162491 \pm 115054^{\mathrm{AB}}$ & \multirow{5}{*}{$5.5-7.37$} & \multirow{5}{*}{$107.71-35.61$} \\
\hline & Chlorophyta & $25004 \pm 27994^{\mathrm{BC}}$ & & \\
\hline & Chrysophyta & $63969 \pm 64405^{\mathrm{BC}}$ & & \\
\hline & Cryptophyta & $20304 \pm 15370^{\mathrm{C}}$ & & \\
\hline & Cyanophyta & $15612 \pm 17451^{\mathrm{C}}$ & & \\
\hline \multirow[t]{5}{*}{ Bare littoral } & Bacillariophyta & $98464 \pm 29471^{B}$ & \multirow{5}{*}{$5.75-7.56$} & \multirow{5}{*}{$106.29-11.75$} \\
\hline & Chlorophyta & $17418 \pm 24188^{\mathrm{CD}}$ & & \\
\hline & Chrysophyta & $77290 \pm 66710^{\mathrm{BC}}$ & & \\
\hline & Cryptophyta & $35814 \pm 14255^{\mathrm{BCD}}$ & & \\
\hline & Cyanophyta & $4345 \pm 5397^{\mathrm{CD}}$ & & \\
\hline \multirow[t]{5}{*}{ Rush beds } & Bacillariophyta & $295566 \pm 195662^{\mathrm{A}}$ & \multirow{5}{*}{$5.72-8.78$} & \multirow{5}{*}{$101.06-6.42$} \\
\hline & Chlorophyta & $415042 \pm 789308^{\mathrm{A}}$ & & \\
\hline & Chrysophyta & $28040 \pm 17210^{\mathrm{A}}$ & & \\
\hline & Cryptophyta & $63796 \pm 56275^{\mathrm{A}}$ & & \\
\hline & Cyanophyta & $29714 \pm 34133^{\mathrm{A}}$ & & \\
\hline \multirow[t]{5}{*}{ Yellow water-lily zone } & Bacillariophyta & $76995 \pm 54563^{\mathrm{B}}$ & \multirow{5}{*}{$6.14-7.31$} & \multirow{5}{*}{$82.62-1.38$} \\
\hline & Chlorophyta & $16439 \pm 15694^{\mathrm{B}}$ & & \\
\hline & Chrysophyta & $63057 \pm 48209^{\mathrm{B}}$ & & \\
\hline & Cryptophyta & $56198 \pm 38639^{\mathrm{B}}$ & & \\
\hline & Cyanophyta & $5583 \pm 4598^{\text {в }}$ & & \\
\hline
\end{tabular}

$\mathrm{N}$ o t e. Grouping information using Tukey test for the abundance of phytoplankton community, different labels (A, B, C, D) show significant differences of main phytoplankton groups among habitats at $p<0.05$.

In Obsterno during May, we achieved a range of 6.47, 6.73, 6.68, 7.16 for C:N and 243.3, 239, 224 and 193.61 for N:P ratio respectively in pelagial, bare littoral, rush beds and yellow water lily zone. In September, C:N ratio of seston was greater than in May for pelagial, bare littoral, rush beds and yellow water lily zone followed by 9.39, 9.36, 8.65 and 8.47. In September N:P ratios were measured by an exceed range of above 1000 (8227, 2348, 2945 and 6392) respectively for pelagial, bare littoral, rush beds and yellow water lily zone which could be a reason of great phosphorus depletion and/or high nitrogen concentration. In May, phosphorus content of seston varied from $6.69 \mu \mathrm{g} / 1$ in littoral and $6.59 \mu \mathrm{g} / \mathrm{l}$ in pelagial but in September, it was recorded as $4.20 \mu \mathrm{g} / 1$ in littoral and $0.80 \mu \mathrm{g} / 1$ in pelagial locations.

Principal Component Analysis of C:N and N:P ratios with phytoplankton abundance expressed some positive but weak correlation in May and September which is followed as: C:N with Dinophyta $(\mathrm{PC}=0.394)$, Chrysophyta $(\mathrm{PC}=0.362)$, Bacillariophyta $(\mathrm{PC}=0.305)$, Chrysophyta $(\mathrm{PC}=0.362)$ and Chlorophyta $(\mathrm{PC}=0.261) ; \mathrm{N}: \mathrm{P}$ with Cyanophyta $(\mathrm{PC}=0.031)$, Dinophyta $(\mathrm{PC}=0.281)$, Cryptophyta $(\mathrm{PC}=0.598)$, Chrysophyta $(\mathrm{PC}=0.015)$ and Bacillariophyta $(\mathrm{PC}=0.409)$. Principal Component Analysis of phosphate and Cryptophyta abundance $(\mathrm{PC}=0.640)$ showed a strong correlation but Chrysophyta $(\mathrm{PC}=0.024)$, Cyanophyta $(\mathrm{PC}=0.007)$ and Dinophyta $(\mathrm{PC}=0.174)$ revealed a poor correlation in Lake Obsterno.

Analysis of variance with post hoc and Tukey test showed the significant differences among phytoplankton groups seasonally $(\mathrm{F}=6.09, p=0.000)$. Grouping information using Tukey method in Lake 
T a b 1 e 4. Taxonomical composition of phytoplankton community of Lake Nobisto: abundance (ind/l) and C:N, N:P ratios of seston in September 2017

\begin{tabular}{|c|c|c|c|c|}
\hline Habitat & Phytoplankton group & Mean \pm SD & $\mathrm{C}: \mathrm{N}$ & $\mathrm{N}: \mathrm{P}$ \\
\hline \multirow[t]{6}{*}{ Pelagial } & Bacillariophyta & $128151 \pm 64114^{\mathrm{AB}}$ & \multirow{6}{*}{10.74} & \multirow{6}{*}{31.09} \\
\hline & Chlorophyta & $35182 \pm 25732^{\mathrm{AB}}$ & & \\
\hline & Chrysophyta & $349740 \pm 382704^{\mathrm{AB}}$ & & \\
\hline & Cryptophyta & $24583 \pm 22678^{\mathrm{AB}}$ & & \\
\hline & Cyanophyta & $12396 \pm 11408^{\text {B }}$ & & \\
\hline & Euglenophyta & $53516 \pm 71750^{\mathrm{AB}}$ & & \\
\hline \multirow[t]{6}{*}{ Bare littoral } & Bacillariophyta & $106270 \pm 42018^{\mathrm{B}}$ & \multirow{6}{*}{12.13} & \multirow{6}{*}{73.73} \\
\hline & Chlorophyta & $31329 \pm 6917^{\mathrm{B}}$ & & \\
\hline & Chrysophyta & $129959 \pm 110072^{\mathrm{B}}$ & & \\
\hline & Cryptophyta & $24392 \pm 20845^{\mathrm{B}}$ & & \\
\hline & Cyanophyta & $8655 \pm 8352^{\mathrm{B}}$ & & \\
\hline & Euglenophyta & $20122 \pm 19254^{\mathrm{B}}$ & & \\
\hline \multirow[t]{6}{*}{ Bull rush } & Bacillariophyta & $104453 \pm 80017^{\mathrm{B}}$ & \multirow{6}{*}{11.61} & \multirow{6}{*}{15.28} \\
\hline & Chlorophyta & $28802 \pm 18720^{\mathrm{B}}$ & & \\
\hline & Chrysophyta & $95117 \pm 48946^{\mathrm{B}}$ & & \\
\hline & Cryptophyta & $30234 \pm 28200^{\mathrm{B}}$ & & \\
\hline & Cyanophyta & $11185 \pm 7984^{\mathrm{B}}$ & & \\
\hline & Euglenophyta & $35729 \pm 30108^{\text {B }}$ & & \\
\hline
\end{tabular}

N o t e. Grouping information using Tukey test for the abundance of phytoplankton community, different labels (A, B) show significant differences of main phytoplankton groups among habitats at $p<0.05$.

Obsterno showed the abundance of Bacillariophyta is significantly different from the other groups in pelagial and bare littoral. As showed in the Tab. 3, mean abundance of Bacillariophyta is higher than others. Beside it, Bacillariophyta had a significant difference with rest of phytoplankton groups during seasons (Tab. 3).

In Lake Nobisto lake during September, C:N ratios were recorded in 10.47, 12.13 and 11.61 respectively for pelagial, bare littoral and bull rush and were higher than its values in Lake Obsterno. N:P showed a range of 31.09, 73.73 and 15.28 for mentioned habitats and were different from those in Lake Obsterno. PCA analysis didn't express an average or strong correlation between phytoplankton groups and CNP as well as water chemistry. Chrysophyta (349-740 ind/1) in May and Bacillariophyta (104-453 ind/1) in September were identified as the most abundant groups from spring to autumn. Grouping information using Tukey method in Lake Nobisto showed that abundance of Bacillariophyta, Chlorophyta, Chrysophyta, Cryptophyta and Euglenophyta in pelagial are significantly different from the abundance of other groups in bare littoral and bull rush during autumn (Tab. 4). Occurrence of $U$. vulgaris may indicate the lack of nitrate nitrogen in Lake Nobisto in autumn as well as low phosphates in comparison with pelagial of Lake Obsterno. Phosphorus content of seston in Lake Nobisto was measured as $7.43 \mu \mathrm{g} / \mathrm{l}$ in pelagial, $3.43 \mu \mathrm{g} / 1$ in bare littoral and $9.51 \mu \mathrm{g} / 1$ in bull rush. In temperate lakes, in mesotrophic systems, most algal taxonomic groups are represented over the growing season, especially Bacillariophyta, Chlorophyta (green algae), Cryptophyta and Dinophyta, as well as Cyanophyta and Chrysophyta [19]. Cryptophyta, Chrysophyta, Chlorophyta and Bacillariophyta increase with phosphorus concentration. Some taxonomic groups increase significantly over a wide phosphorus range (Cyanophyta, Bacillariophyta), others exhibit decelerating rates of increase at low (Chrysophyta) or moderate P levels (Cryptophyta, Dinophyta) [20]. As it is shown in our survey, phosphate and Cryptophyta showed a strong correlation but a poor correlation with the rest of phytoplankton groups in Lake Obsterno. This result in marked shifts in average phytoplankton taxonomic composition across this intermediate phosphorus range. McQueen and Lean [21] claimed that Chrysophyta and Dinophyta show a decelerating rate in their growth when $\mathrm{P}$ is low or moderate, as they decreased in May and in early summer but then decelerated toward autumn in Lake Obsterno. High light, $\mathrm{N}: \mathrm{P}$ and intermediate $\mathrm{pH}$ and temperatures may favour Chlorophyta [22]. Chlorophyta in Lake 
Obsterno appeared more abundant in late summer and early autumn where temperature and light were higher than spring [16]. Both Cryptophyta and Chrysophyta exploit nutrient and light gradients [23] and conditions associated with enrichment (increased turbidity and organic materials) favour their growth which is in agreement with our obtained data with highest abundance of Cryptophyta and Chrysophyta in May for both lakes. On the other hand, most cryptophytes and many chrysophytes are small monads, and grazing regulation should significantly modify their response to nutrient enrichment [24]. Chrysophyta have been shown to be frequently phosphorus limited, but they respond unpredictably to enrichment [23]. The comparatively strong relationship between phosphate and Cryptophyta abundance $(\mathrm{PC}=0.640)$ in our data suggests that this group is more influenced by phosphorus. On the other side a poor correlation between phosphate with Chrysophyta, Cyanophyta and Dinophyta suggest that they could be affected by $\mathrm{pH}$ and alkalinity [23] which is common among many of these taxa than phosphorus [25, 26]. According to the PEG-model of plankton seasonal succession toward the spring, nutrient availability and increased light permit unlimited growth of phytoplankton, especially in Cryptophyta and small diatoms. In the middle of warm season, by more soluble phosphorus, Cryptophyta become predominant as its clear in studied lakes. By seasonal changes and light limitation from spring to autumn, macrophytes and vegetation become important particularly in shallow lakes as it happened in both our studied lakes [27]. Macrophytes are known to affect nutrient cycling in lakes causing changes in phytoplankton biomass, growth and leading to competition among different taxa [28], but there is no effect on the presence or absence of macrophytes on the total biomass of diatoms [29] as its shown in our survey suggesting not only hydrochemical but other factors affect on phytoplankton dynamics.

Conclusion. A synthesis of patterns in average spring and autumnal abundance of major phytoplankton taxonomic groups in mesotrophic Lake Obsterno show that all groups increase in abundance with soluble phosphorus at different degrees, but only Cryptophyta showed a strong correlation over the season. However, neither abundance of dominant phytoplankton groups, nor chlorophyll $a$ content didn't show any correlations of taxonomic composition with the range of nutrient levels observed. Contrary, in shallow low trophic Lake Nobisto mainly nutrient deficiency and competition with macrophytes leads to development and changing defined phytoplankton groups especially in pelagial. We also approve that Phyto-Pam has been limited by the fact that it cannot distinguish between different phytoplankton groups, like green algae, diatoms and blue-green algae and it's just a quick method for analysis of the main algal pigments.

Acknowledgements. This work was supported by Belarusian Republican Foundation for Fundamental Research, grant no. B17-037. Field sampling in 2016 was performed in frame of the State Programme of Scientific Researches of Belarus (Nature management and Ecology, task 2.06, 2016-2018, no. 20160496). We also would like to acknowledge Belarus National Academy of Science for financial support and Prof. L. Senerpont Domis to provide the opportunity to visit the Institute of Ecology (NIOO-KNAW) in Wageningen, for the help and supervision working on Phyto Pam analyser.

Благодарности. Работа выполнена при поддержке Белорусского фонда фундаментальных исследований (грант № Б17-037). Сбор материала в 2016 г. был проведен при поддержке ГПНИ (Природопользование и экология, задание 2.06, № ГР 20160496). Выражаем благодарность НАН Беларуси за финансовую поддержку и профессору Лизетт Сенерпонт Домис из Института экологии (NIOO-KNAW, Вагенинген, Нидерланды) за помощь в освоении методики для работы на Phyto-Pamанализаторе.

\section{References}

1. Gerten D., Adrian R. Climate-driven changes in spring plankton dynamics and the sensitivity of shallow polymictic lakes to the North Atlantic Oscillation. Limnology and Oceanography, 2000, vol. 45, no. 5, pp. 1058-1066. https://doi.org/ 10.4319/ lo.2000.45.5.1058

2. Lampert W., Sommer U. Limnoecology - the ecology of lakes and streams. 1st ed. New York, Oxford University Press, 1997. $382 \mathrm{p}$.

3. Marker A. F. H., Nusch E. A., Rai H., Riemann B. The measurements of photosynthetic pigments in freshwaters and standardization of methods: conclusions and recommendations. Archiv für Hydrobiologie, 1980, vol. 14, pp. 91-106.

4. Lorenzen C. J. Determination of chlorophyll and phaeo-pigments: spectrophotometric equations. Limnology and Oceanography, 1967, vol. 12, no. 2, pp. 343-346. https://doi.org/10.4319/lo.1967.12.2.0343

5. Jeffrey S. W. An improved thin-layer chromatographic technique for marine phytoplankton pigments. Limnology and Oceanography, 1981, vol. 26, no. 1, pp. 191-197. https://doi.org/10.4319/10.1981.26.1.0191

6. Søndergaard M. Seasonal variations in the loosely sorbed phosphorus fraction of the sediment of a shallow and hypertrophic lake. Environmental Geology and Water Sciences, 1988, vol. 11, pp. 115-121. https://doi.org/10.1007/BF02587770 
7. Lorenzen C. J. A method for the continuous measurement of in vivo chlorophyll concentration. Deep Sea Research and Oceanographic Abstracts, 1966, vol. 13, no. 2, pp. 223-227. https://doi.org/10.1016/0011-7471(66)91102-8

8. Falkowski P. G., Kolber Z. Variations in chlorophyll fluorescence yields in phytoplankton in the world oceans. Australian Journal of Plant Physiology, 1995, vol. 22, no. 2, pp. 341-355. https://doi.org/10.1071/pp9950341

9. Kolber Z., Falkowski P. G. Use of active fluorescence to estimate phytoplankton photosynthesis in situ. Limnology and Oceanography, 1993, vol. 38, no. 8, pp. 1646-1665. https://doi.org/10.4319/lo.1993.38.8.1646

10. Schreiber U., Bilger W. Progress in chlorophyll fluorescence research: major developments during the past years in retrospect. Progress in botany. Vol. 54. Berlin, 1993, pp. 151-173.

11. Kolbowski J., Schreiber U. Computer-controlled phytoplankton analyser based on 4 wavelengths PAM chlorophyll fluorometer. Photosynthesis: from Light to Biosphere. Dordrecht, 1995, pp. 825-828.

12. Staehr P. A., Baastrup-Spohr L., Sandjensen K., Stedmon C. Lake metabolism scales with lake morphometry and catchment conditions. Aquatic Sciences, 2012, vol. 74, no. 1, pp. 155-169. https://doi.org/10.1007/s00027-011-0207-6

13. They N. H., Motta-Marques D., Souza R. S. Lower respiration in the littoral zone of a subtropical shallow lake. Frontiers in Microbiology, 2013, vol. 3, art. 434. https://doi.org/10.3389/fmicb.2012.00434

14. Murphy J., Riley J. P. A modified single-solution method for the determination of phosphorus in natural waters. Analytica Chimica Acta, 1962, vol. 27, pp. 31-36. https://doi.org/10.1016/s0003-2670(00)88444-5

15. Sommer U., Gliwicz Z. M., Lampert W., Duncan A. PEG-model of seasonal succession of planktonic events in fresh waters. Archiv für Hydrobiologie, 1986, vol. 106, no. 4, pp. 433-471.

16. Happy-Wood C. M. Ecology of freshwater planktonic green algae. Growth and reproductive strategies of freshwater phytoplankton. Cambridge, 1988, pp. 103-133.

17. Moore J. W. Distribution and abundance of phytoplankton in 153 lakes, rivers, and pools in the Northwest Territories. Canadian Journal of Botany, 1978, vol. 56, no. 15, pp. 1765-1773. https://doi.org/10.1139/b78-210

18. Flett R. J., Schindler D. W., Hamilton R. E., Campbell N. E. R. Nitrogen fixation in the Precambrian Shield lakes. Canadian Journal of Fisheries and Aquatic Sciences, 1980, vol. 37, no. 3, pp. 494-505. https://doi.org/10.1139/f80-064

19. Eloranta P. Melosira distans var. tenella and Eunotia zasuminensis, two poorly known planktonic diatoms in Finnish lakes. Nordic Journal of Botany, 1986, vol. 6, no. 1, pp. 99-103. https://doi.org/10.1111/j.1756-1051.1986.tb00865.x

20. Reynolds C. S. Phytoplankton periodicity: the inetraction of from, fuction and environmental variability. Freshwater Biology, 1984, vol. 44, no. 2, pp. 111-142. https://doi.org/10.1111/j.1365-2427.1984.tb00027.x

21. McQueen D. J., Lean D. R. S. Influence of water temperature and nitrogen to phosphorus ratios on the dominance of blue-green algae in lake St. George, Ontario. Canadian Journal of Fisheries and Aquatic Sciences, 1987, vol. 44, no. 3, pp. 598-604. https://doi.org/10.1139/f87-073

22. Tilman, D., Kiesling K., Sterner R., Kilham S. S., Johnson A. Green, blue-green and diatom algae: taxonomic differences in competitive ability for phosphorus, silicon and nitrogen. Archiv für Hydrobiologie, 1986, vol. 106, pp. 473-485.

23. Sandgren C. D. The ecology of chrysophyte flagellates: their growth and perennation strategies as freshwater phytoplankton. Growth and reproductive strategies of freshwater phytoplankton. Cambridge, 1988, pp. 9-104.

24. Watson S., McCauley E. Contrasting patterns of net and nanoplankton production and biomass among lakes. Canadian Journal of Fisheries and Aquatic Sciences, 1988, vol. 45, no. 5, pp. 915-920. https://doi.org/10.1139/f88-112

25. Caron D. A., Dam H. G., Kremer P., Lessard E. J., Madin L. P., Malone T. C., Napp J. M., Peele E. R., Roman M. R., Youngbluth M. J. The contribution of microorganisms to particulate carbon and nitrogen in surface waters of the Sargasso Sea near Bermuda. Deep-Sea Research. Part I: Oceanographic Research Papers, 1995, vol. 42, no. 6, pp. $943-972$. https://doi.org/10.1016/0967-0637(95)00027-4

26. Downing J. A., McCauley E. The nitrogen: phosphorus relationship in lakes. Limnology and Oceanography, 1992, vol. 37, no. 5, pp. 936-945. https://doi.org/10.4319/lo.1992.37.5.0936

27. Cox E. J. Identification of Freshwater Diatoms from Live Material. London, Chapman \& Hall Publ., 1996. 158 p.

28. O’Dell K. M., Van Arman J., Welch B. H., Hill S. D. Changes in water chemistry in a macrophyte-dominated lake before and after herbicide treatment. Lake and Reservoir Management, 1995, vol. 11, no. 4, pp. 311-316. https://oi.org/10.1080/ 07438149509354212

29. Beklioglu M., Moss B. Mesocosm experiments on the interaction of sediment influence, fish predation and aquatic plants with the structure of phytoplankton and zooplankton communities. Freshwater Biology, 1996, vol. 36, no. 2, pp. 315-325. https://doi.org/10.1046/j.1365-2427.1996.00092.x

\section{Information about the authors}

Zhanna F. Buseva - Ph. D. (Biol.), Leading Researcher. Scientific and Practical Center for Bioresources of the National Academy of Sciences of Belarus (27, Akademicheskaya Str., 220072, Minsk, Republic of Belarus). E-mail: buseva_j@mail.ru

Shabnam G. Farahani - Postgraduate student, Junior Researcher. Scientific and Practical Center for Bioresources of the National Academy of Sciences of Belarus (27, Akademicheskaya Str., 220072, Minsk, Republic of Belarus). E-mail: sh.farahani1986@gmail.com

\section{Информация об авторах}

Бусева Жанна Федоровна - канд. биол. наук, вед. науч. сотрудник. Научно-практический центр НАН Беларуси по биоресурсам (ул. Академическая, 27, 220072, г. Минск, Республика Беларусь). E-mail: buseva_j@mail.ru

Фарахани Шабнам Газерани - аспирант, мл. науч. сотрудник. Научно-практический центр НАН Беларуси по биоресурсам (ул. Академическая, 27, 220072, г. Минск, Республика Беларусь). E-mail: sh.farahani1986@gmail.com 
Elena A. Sysova - Ph. D. (Biol.), Senior Researcher. Scientific and Practical Center for Bioresources of the National Academy of Sciences of Belarus (27, Akademicheskaya Str., 220072, Minsk, Republic of Belarus). E-mail: sysovaelena@mail.ru

Davis Ozolins - Researcher. Institute of Biology of the University of Latvia (3, Mier Str., LV-2169, Salaspils, Latvia). E-mail: davis.ozolins@lu.lv

Nadezhda N. Sushchik - D. Sc. (Biol.), Leading Researcher, Deputy Director. Institute of Biophysics of the Siberian Branch of the Russian Academy of Sciences (50/50, Akademgorodok, 660036, Krasnoyarsk, Russian Federation). E-mail: labehe@ibp.ru

Angelika A. Kolmakova - Ph. D. (Biol.), Senior Researcher. Institute of Biophysics of the Siberian Branch of the Russian Academy of Sciences (50/50, Akademgorodok, 660036, Krasnoyarsk, Russian Federation). E-mail: angelika@inbox.ru

Yulia K. Veras - Ph. D. (Biol.), Deputy Director. Belarusian State University (Minsk Region, 220095, Naroch, Republic of Belarus). E-mail: veres.julia.naroch@gmail.com
Сысова Елена Александровна - канд. биол. наук, ст. науч. сотрудник. Научно-практический центр НАН Беларуси по биоресурсам (ул. Академическая, 27, 220072, г. Минск, Республика Беларусь). E-mail: sysovaelena@mail.ru

Озолиньш Дэвис - науч. сотрудник. Институт биологии, Латвийский университет (ул. Миера, 3, LV-2169, г. Саласпилс, Латвия). E-mail: davis.ozolins@lu.lv

Сущик Надежда Николаевна - д-р биол. наук, вед. науч. сотрудник, заместитель директора. Институт биофизики Сибирского отделения Российской академии наук (Академгородок, 50/50, 660036, г. Красноярск, Российская Федерация). E-mail: labehe@ibp.ru

Колмакова Анжелика Александровна - канд. биол. наук, ст. науч. сотрудник. Институт биофизики Сибирского отделения Российской академии наук (Академгородок, 50/50, 660036, г. Красноярск, Российская Федерация). E-mail: angelika@inbox.ru

Верес Юлия Константиновна - канд. биол. наук, заместитель директора. Белорусский государственный университет (220095, Нарочь, Минская область, Республика Беларусь). E-mail: veres.julia.naroch@gmail.com 